\title{
AN ANALYSIS OF THE INFLUENCE DOUBLE NORMALIZATION PROCESS ON MECHANICAL PROPERTIES AND MICROSTRUCTURE 38MNVS6 STEEL
}

\author{
Dominika SIWIEC ${ }^{1}$, Renata DWORNICKA ${ }^{2}$, Andrzej PACANA ${ }^{3}$ \\ ${ }^{1}$ Rzeszow University of Technology, Rzeszow, Poland, EU, ORCID ID: 0000-0002-6663-6621 \\ d.siwiec@prz.edu.pl, \\ ${ }^{2}$ Cracow University of Technology, Cracow, Poland, EU, ORCID ID: 0000-0002-2979-1614 \\ renata.dwornicka@mech.pk.edu.pl, \\ ${ }^{3}$ Rzeszow University of Technology, Rzeszow, Poland, EU, ORCID ID: 0000-0003-1121-6352 \\ app@prz.edu.pl,
}

https://doi.org/10.37904/metal.2021.4162

\begin{abstract}
The aim of the article is to analyse of the impact the double normalization process of 38MnVS6 micro-alloy steel on the achievement of the required microstructure and selected mechanical properties. The analysis was made based on values of elongation at break and the criterion of the minimum permissible breaking work. The products used in the automotive industry were analysed. It were the forgings from $38 \mathrm{MnVS} 6$ steel in ball-shape and weights $28 \mathrm{~N}$ forged at a temperature of $1250^{\circ} \mathrm{C}$. It was shown that the double normalization process of $38 \mathrm{MnVS} 6$ steel was improved its microstructure and allowed on achieving the needs mechanical properties. The results shown in the work can be useful for other enterprises to achieve the effective processing of products, e.g. from the automotive industry.
\end{abstract}

Keywords: 38MnVS6, properties, mechanical engineering, normalization process, quality of product

\section{INTRODUCTION}

Improving the production process of the products includes for example reduction of heat treatment time [1-4], and the improvement of product properties. It is possible by using micro-alloy steel. These steels in compared e.g. to alloy steels [5] allow for reducing the production costs even to $30 \%$ [6]. It results from not needs to subjecting these steels to hardening and tempering $[6,7]$. The popular micro-alloy steel is $38 \mathrm{MnVS} 6$ steel (38MnSiVS5 or 38MnVS5) $[7,8]$. This steel is mainly used in the automotive industry for production of products in the form of forgings. The examples are crankshafts and also engine pistons [9-12]. The literature review has shown a need to make an analysis of the $38 \mathrm{MnVS} 6$ steel [12,13]. For example in work [13], it was shown that by added $0.05 \% \mathrm{Nb}$ it is possible to achieve the maximum hardness of steel and tensile strength. This hardness was $200 \mathrm{HV}$, while the tensile strength was equal to $720 \mathrm{MPa}$. It was shown, that normalization of the steel with the addition of the niobium allows for achieving the homogeneous microstructure and fine perlite colonies evenly distributed in the ferrite. Then, in the work [14] the impact of additives on 38MnVS6 steel was analysed. The impact of manganese sulphides on the fatigue life of 38MnVS6 steel was analysed. The Wohler curves were used for that. These curves were appropriate at high nominal stress amplitude levels compared to the forged material [14]. Additionally, it was shown the positive relationship between shape and manganese sulfide content, taking into account the forging process and the fatigue life of the material. In turn, the authors of work [15] were analysed the additional tellurium to $38 \mathrm{MnVS6}$ steel. It was shown that the diameter of the inclusions increased with increasing tellurium content in the steel. The proportion factor of inclusions was small. Then, the authors of work [16] have shown the influence the heating 38MnVS6 steel on the weld structure during laser welding. Also, it was researching the mechanical properties of the welded joints in different preheating temperatures. The results were shown that e.g. preheating allows the greater laser absorption 
capacity of the metal, what is generates an increase in the width of the weld. Despite in the work [17], deformation of hot-rolled micro-alloyed steel bars 38MnVS6 was shown by the MES model. It was concluded that the proposed model allows on optimize: groove geometry, roll transition schedule, and mill parameters and temperature. Wherein, the aim was to achieve a better quality and product performance. Then, in publications [18-20] it was presented the mathematical models of dynamic recrystallization (DRX) and steel grain growth $38 \mathrm{MnVS} 6$ hot compression tests. Also, the tests of isothermal annealing on the Gleeble-1500 thermomechanical simulator were made. Among other things, it was found that the simulated mean values of the full-grain size DRX showed good agreement with the measured. Another example is work [21], in which the hot flow stresses of $38 \mathrm{MnVS} 6$ steel were analyzed. These stresses were described by Cingar and McQueen, JMAK or Hensel-Spittel equations. The graphical and statistical comparison was shown that e.g. the predicted curve of the flow according to the proposed model enables adjustment to the experimental data. Additionally, the authors of work [22] have presented the production of 38MnVS5 steel as part of improving its quality. Except that, the vat slag with alkalinity $\left(\mathrm{CaO} / \mathrm{Al}_{2} \mathrm{O}_{3}\right)$ and an indicator that enables the improvement of desulphurization and absorption capacity in steel was designed.

Based on the literature review it was concluded, that previous analyses did not cover the issues of double normalization of the $38 \mathrm{MnVS} 6$ steel. It can result from the fact that is important to limit the number of heat treatments. Thanks to that it is possible to reduce the production costs. However, the enterprises still researching for different treatments, thanks for which the right combination of properties, i.e. strength, impact strength, as well as proper fragmentation of the microstructure, will be achieved. This type of problem was solved by performing double normalization of $38 \mathrm{MnVS} 6$ steel in one of the Podkarpacie enterprises. Therefore, the aim of the article is to analyse the impact of the double normalization process of 38MnVS6 micro-alloy steel on achieving the required microstructure and selected mechanical properties. The analysis was made based on research results obtained from Forgex Polska Sp. z o. o. enterprise localized at Podkarpacie in Poland. The article is a continuation of the article [23], in which the yield strength, tensile strength and Brinell hardness were analysed.

The obtained results, documenting a significant improvement in the technological properties of steel and a strong reduction in costs, may be of interest to a wide group of industrial recipients, including in the field of quality $[24,25]$ and risk management [26, 27], corrosion protection [28, 29] and the use of structural steel in construction [30] and railways [31-33]. The subject matter may also be interesting for the research area, where work on the corrosion protection of materials [34-36] and their coatings [37] is still in progress, as it determines the operation of laboratory equipment in aggressive biological environments [38]. The results should also be valuable as a source of data for the area of mechanics [39,40], including fracture toughness [41] and material sciences [42, 43]. The obtained data set can also be a valuable source of inspiration in the development of analytical methods, both image analysis [44-47], parametric [48-50] and non-parametric [51] prediction models.

\section{SUBJECT OF STUDY AND MATERIAL}

The research was in aim to achieve the required microstructure and selected mechanical properties of $38 \mathrm{MnVS} 6$ micro-alloy steel. The required was to achieve elongation at break $\geq 15 \%$, and the criterion of the minimum allowable breaking work equal to $27 \mathrm{~J}$. The measures were made on ZWICK BZ200/SN6S-M testing machine and Charpy LabTest CHK300J impact hammer. The research was realized based on three forgings from $38 \mathrm{MnVS} 6$ steel has applied in the automotive industry. The characteristic of the subject of study and description of the double normalization process of 38MnVS6 micro-alloy steel were shown in the work: [23].

\section{RESULTS}

The results of double normalization of 38MnVS6 micro-alloy steel are shown in Table 1. 
Table 1 The results of double normalization of 38MnVS6 micro-alloy steel

\begin{tabular}{|c|c|c|c|}
\hline Step of normalization process & Sample number & $\begin{array}{c}\text { Elongation at break } \\
\text { (A5, \%) }\end{array}$ & $\begin{array}{c}\text { The criterion of the } \\
\text { minimum allowable } \\
\text { breaking work } \\
\text { (KV }\end{array}$ \\
\hline Material from the smelter & $1-2-3$ & $20.6-20.8-19.1$ & $36.5-36.8-57.3$ \\
\hline A bite steel after forging & $1-2-3$ & $16.3-11.7-11.3$ & $6.5-7.9-5.5$ \\
\hline Forging without heat treatment & $1-2-3$ & $14.5-9.7-14.7$ & $8.1-9.2-12.3$ \\
\hline Forging after normalization & $1-2-3$ & $19.4-20.7-21.5$ & $28.4-43.9-37.4$ \\
\hline Forging after normalization twice & $1-2-3$ & $22.26-21.83-22.71$ & $36.1-36.4-34.1$ \\
\hline
\end{tabular}

It was shown that the selected mechanical properties of 38MnVS6 micro-alloy steel for the process of bite after forging and for forging without heat treatment were definitely below the required values. While the required properties for forgings after double normalization were achieved. Wherein, after double normalization, the increase elongation at break from $19.4 \%$ to $22.71 \%$ was obtained. The values of this property for one normalization from $19.4 \%$ to $21.5 \%$ were determined, in turn for double normalization from $21.83 \%$ to 22.71 $\%$ (i.e. minimum and maximum values of three forgings). Additionally, it was shown that the double normalization process allows achieving required values of the criterion of the minimum breaking work, i.e. from $28.4 \mathrm{~J}$ to $36.4 \mathrm{~J}$ (i.e. the minimum value, after one normalization and maximum value after double normalization). In the case of the forgings subjected to double normalization, it was observed that this process allows an increase in the value of the breaking work from $5.5 \mathrm{~J}$ (value for the bite after the forging process) to $36.4 \mathrm{~J}$. Therefore, it was considered that the process of double normalization was effective. It is important to mention that it was necessary to achieve not only the currently analysed properties but also the properties presented and analysed in the previous article [i. e.: 18], i.e. yield strength, tensile strength, and hardness, which were also met after applying double normalization.

The example of the microstructure of 38MnVS6 micro-alloy steel before and after the double normalization is shown in Figure 1. The microstructure was examined with an OLYMPUS PMG 3 metallographic optical microscope.

a)

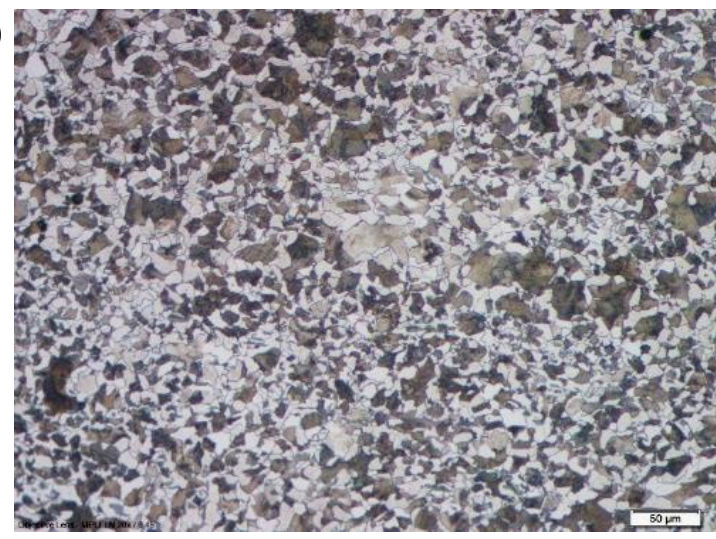

b)

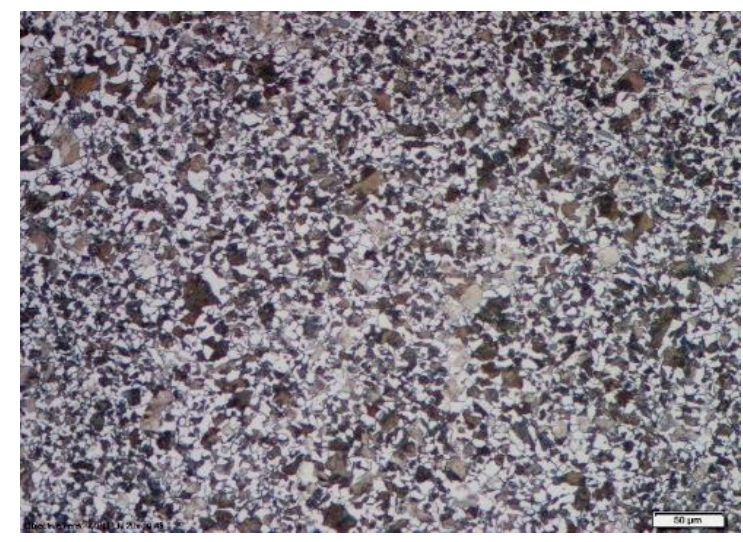

Figure 1 The comparison of microstructure the 38MnVS6 micro-alloy steel at 200 times magnification, nital digestion: a) after one normalization, b) after double normalization

The double normalization process made it possible to achieve the required homogeneous, fine-grained pearlitic-ferritic microstructure of the 38MnVS6 micro-alloy steel. 


\section{CONCLUSION}

The improvement of mechanical properties of the products is possible in effect by the normalization processes. These processes are effective for micro-alloy steels, which are more popular in the automotive industry than alloy steels. One of the often use steel is 38MnVS6 micro-alloy steel. However, it has been shown that so far this steel has not undergone a double normalization process in order to achieve its required mechanical properties and microstructure. Therefore, the aim of the article was to analyse the impact of the double normalization process of $38 \mathrm{MnVS} 6$ micro-alloy steel on achieving the required microstructure and selected mechanical properties. The problem with achieving the required mechanical properties and microstructure this steel was solved in Forgex Polska Sp. z o. o. enterprise localized at Podkarpacie in Poland. The analysis has included the properties of elongation at break and the criterion of the minimum allowable breaking work. The products were the forgings from $38 \mathrm{MnVS} 6$ steel in ball-shape and weights $28 \mathrm{~N}$ forged at a temperature of $1250{ }^{\circ} \mathrm{C}$. The conducted analysis showed that the double normalization process allows to obtain the recommended elongation at break properties from $21.83 \%$ to $22.71 \%$ and the criterion of the minimum allowable breaking work from $34.1 \mathrm{~J}$ to $36.1 \mathrm{~J}$. Additionally, it was concluded that this process provided a homogeneous, fine-grained structure. For this reason, the results presented in the article may be useful for other companies in achieving effective processing of products, e.g. from the automotive industry.

\section{REFERENCES}

[1] EBRAHIMI A., MOSHKAR MM. Study of machinability in boring operation of microalloyed and heat-treated alloy steels. Materials Science and Engineering: A. 2007, vol. 460-461, pp. 314-323.

[2] PACANA A., et al. Discrepancies analysis of casts of diesel engine piston, Metalurgija. 2018. vol. 57, pp. 324-326.

[3] OSTASZ G., et al. Quality management of aluminum pistons with the use of quality control points. Management Systems In Production Engineering. 2020, vol. 28, pp. 29-33.

[4] PACANA A., BEDNAROVA L, LIBERKO I., et al. Effect of selected production factors of the stretch film on its extensibility. Przem. Chem. 2014, vol. 93, pp. 1139-1140.

[5] DING J., ZHANG YJ., CHEN YB. Effect of controlled forging and cooling process on structure of 38MnVS5 microalloyed steel. Trans. of Materials and Heat Treatment. 2006, vol. 27(5), pp. 35-38.

[6] NIU D., ZHANG J., XIONG P., HAO G., LIU S., GUO W. High temperature fatigue and oxidation characteristics of forged steel piston materials. Engineering Failure Analysis. 2019, vol. 97, pp. 220-226.

[7] GU S., ZHANG L., ZHANG, C. et al. Modeling the Effects of Processing Parameters on Dynamic Recrystallization Behavior of Deformed 38MnVS6 Steel. J. Mater. Eng. Perform. 2015, vol. 24, pp. 1790-1798.

[8] VIDHYASAGAR M., BALACHANDRAN G. An Assessment of Ladle Furnace Steel-making Reactions in an Aluminium-Killed 38MnS6 Steel. Trans. of the Indian Institute of Metals. 2020, vol. 73, 479-495.

[9] CHINCHANIKAR, S., KORE, S.S., HUJARE, P. A review on nanofluids in minimum quantity lubrication machining. J. Manuf. Processes. 2021, vol. 68, pp. 56-70.

[10] MAKESHKUMAR M., ANBURAJ J. Study of combined effect of zirconium and titanium on microstructure and mechanical properties of micro-alloyed cast steels. Materials Research Express. 2019, vol. 6, no. $1065 \mathrm{~d} 8$.

[11] PACANA, A., PASTERNAK-MALICKA M., ZAWADA M. et al. Decision support in the production of packaging films by cost-quality analysis. Przem. Chem. 2016, vol. 95, pp. 1042-1044.

[12] SCURRIA, M., EMRE, S., MOELLER, B. et al. Evaluation of the Influence of MnS in Forged Steel $38 M n V S 6$ on Fatigue Life. SAE Int. J. Engines. 2017, vol. 10(2), pp. 366-372.

[13] OKAN, T., MUSTAFA, U. On the microstructural and mechanical characterizations of a low carbon and microalloyed steel. Materials \& Design. 2009, vol. 30(8), pp. 3274-3278.

[14] LARRUCEA, X. MOFFIE, M., ASAF, S. et al. Towards a GDPR compliant way to secure European cross border Healthcare Industry 4.0. Computer Standards \& Interfaces. 2020, vol. 69, pp. 1-7.

[15] KIMURA, T.; KUREBAYASHI, Y. Niobium in Microalloyed Engineering Steels, Wire Rods and Case Carburized Products. In: Proc. 2001 Int. Symposium on Niobium, TMS 2001. Orlando, FL, USA, 2-5 December 2001. pp. 801-820. 
[16] SU, J., QIU, X., XING, F. et al. Effect of Preheating Temperature on Microstructure and Properties of 42CrMo4/38MnVS6 Heterogeneous Laser Welded Joint. METALS. 2019, vol. 9(8), no. 870.

[17] NALAWADE, R. S., MARJE, V. R., BALACHANDRAN, G. et al. Effect of pass schedule and groove design on the metal deformation of $38 \mathrm{MnVS} 6$ in the initial passes of hot rolling. Sadhana-Academy Proceedings in Engineering Sciences. 2016, vol. 41, pp. 111-124.

[18] PACANA, A., SIWIEC, D., BEDNAROVA, L. Analysis of the incompatibility of the product with fluorescent method. Metalurgija. 2019. vol. 58, pp. 337-340.

[19] GU, S., ZHANG, L., ZHANG, C. ET al. Modeling the Effects of Processing Parameters on Dynamic Recrystallization Behavior of Deformed 38MnVS6 Steel. J. Mater. Eng. Perform. 2015, vol. 24, pp. 1790-1798.

[20] GU, S., ZHANG, L., RUAN, J. et al. Constitutive Modeling of Dynamic Recrystallization Behavior and Processing Map of 38MnVS6 Non-Quenched Steel. J. Mater. Eng. Perform. 2014, vol. 23, pp.1062-1068.

[21] OPELA, P., SCHINDLER, I., KAWULOK, P. et al. New Model Predicting Flow Curves In Wide Range Of Thermomechanical Conditions Of 38MnVS6 Steel. In: METAL 2020, 25th Int. Conf. on Metall. and Mater. Ostrava: TANGER, pp. 458-463.

[22] VIDHYASAGAR, M., BALACHANDRAN, G. An Assessment of Ladle Furnace Steel-making Reactions in an Aluminium-Killed 38MnS6 Steel. Transactions of the Indian Institute of Metals. 2020, vol. 73, pp. 479-495.

[23] SIWIEC, D., DWORNICKA, R., PACANA, A. Improving the process of achieving required microstructure and mechanical properties of 38MnVS6 steel. In: METAL 2020, 29th Int. Conf. on Metall. and Mater. Ostrava: TANGER, 2020, pp. 591-596.

[24] MICHNA, S., NAPRSTKOVA, N., KLIMECKA-TATAR, D. Research the causes of surface stains after eloxal coating for the profile from the AIMgSi alloy using substructural analysis. Manuf. Technol. 2015, vol. 15, pp. 620624.

[25] KRYNKE, M., MIELCZAREK, K. Applications of linear programming to optimize the cost-benefit criterion in production processes. MATEC Web of Conf. 2018, vol. 183, no. 04004.

[26] KOZIEN, E., KOZIEN, M.S. The EX ante risk assessment in the project in interval analysis description. Materials Research Proceedings. 2020, vol. 17, pp. 31-35.

[27] MYRCZEK, J., JURASZEK, J., TWOREK, P. Risk management analysis in construction enterprises in selected regions in Poland. Technical Transactions. 2020, vol.117, no. e2020025.

[28] LIPINSKI, T., KARPISZ, D. Eeffect of modification time on microstructure and tensile strength alsi9mg alloy with sr, ti and b additions using in agricultural machinery. Engineering for Rural Development. 2020, vol. 19, pp. 14761481.

[29] LIPINSKI, T., KARPISZ, D. Effect of animal slurry on carbon structural S235jr steel at $303 \mathrm{~K}$. Engineering for Rural Development. 2020, vol. 19, pp. 1482-1487.

[30] MAJEWSKI, G., ORMAN, Ł.J., TELEJKO, M., RADEK, N., PIETRASZEK, J., DUDEK, A. Assessment of thermal comfort in the intelligent buildings in view of providing high quality indoor environment. Energies. 2020, vol. 13, no. 1973.

[31] KRYNKE, M., BORKOWSKI, S., SELEJDAK, J. Analysis of influence of bearing clearance on the static carrying capacity of multi-row slewing bearings. Periodica Polytechnica Transportation Engineering. 2014, vol. 42, pp. 4348.

[32] KRYNKE, M., ULEWICZ, R. Analysis of the influence of slewing bearing mounting on their static load capacity. Transportation Research Procedia. 2019, vol. 40, pp. 745-750.

[33] MYSŁEK, A. Crack propagation analysis in selected railway bogie components. Technical Transactions. 2020, vol.117, no. e2020017.

[34] WŁODARCZYK, R., DUDEK, A., NITKIEWICZ, Z. Corrosion analysis of sintered material used for lowtemperature fuel cell plates. Arch. Metall. Mater. 2011, vol. 56, pp. 181-186.

[35] KLIMECKA-TATAR, D., PAWLOWSKA, G., ORLICKI, R., ZAIKOV, G.E. Corrosion characteristics in acid, alkaline and the ringer solution of Fe68-xCoxZr10Mo5W2B 15 metallic glasses. J. Balk. Tribol. Assoc. 2014, vol. 20, pp. 124-130.

[36] LIPINSKI, T. Corrosion effect of $20 \% \mathrm{NaCl}$ solution on basic carbon structural S235JR steel. Engineering for Rural Development. 2017, vol. 16, pp. 1069-1074. 
[37] JAGIELSKA-WIADEREK, K., BALA, H., WIECZOREK, P., RUDNICKI, J., KLIMECKA-TATAR, D. Corrosion resistance depth profiles of nitrided layers on austenitic stainless steel produced at elevated temperatures. Arch. Metall. Mater. 2009, vol. 54, pp. 115-120.

[38] SKRZYPCZAK-PIETRASZEK, E., URBANSKA, A., ZMUDZKI, P., PIETRASZEK, J. Elicitation with methyl jasmonate combined with cultivation in the Plantform ${ }^{\mathrm{TM}}$ temporary immersion bioreactor highly increases the accumulation of selected centellosides and phenolics in Centella asiatica (L.) Urban shoot culture. Engineering in Life Sciences. 2019. vol. 19, pp.931-943.

[39] KOZIEŃ, M.S., WICIAK, J. Passive structural acoustic control of the smart plate - FEM simulation. Acta Phys. Pol. A. 2010, vol. 118, pp. 1186-1188.

[40] AUGUSTYN, E., KOZIEŃ, M.S., PRĄCIK, M. FEM analysis of active reduction of torsional vibrations of clampedfree beam by piezoelectric elements for separated modes. Arch. Acoust. 2014, vol. 39, pp. 639-644.

[41] GUIDONI, G., DUDEK, A., PATSIAS, S., ANGLADA, M. Fracture behaviour of thermal barrier coatings after high temperature exposure in air. Mater. Sci. Eng. A. 2005, vol. 397, pp. 209-214.

[42] LIPINSKI, T. Modification of Al-11\% Si alloy with Cl-based modifier. Manuf. Technol. 2015, vol. 15, pp. 581-587.

[43] SZCZOTOK, A., PIETRASZEK, J., RADEK, N. Metallographic Study and Repeatability Analysis of y' Phase Precipitates in Cored, Thin-Walled Castings Made from IN713C Superalloy. Arch. Metall. Mater. 2017, vol. 62, pp. 595-601.

[44] GADEK-MOSZCZAK, A., SABINA, Z. Description of 3D microstructure of the composites with polypropylene (PP) matrix and tuf particles fillers. Solid State Phenom. 2013, vol. 197, pp. 186-191.

[45] KORZEKWA, J., GĄDEK-MOSZCZAK, A., BARA, M. The influence of sample preparation on SEM measurements of anodic oxide layers. Prakt. Metallogr.-Pract. Metallogr. 2016, vol. 53, pp. 36-49.

[46] RADEK, N., SZCZOTOK, A., GĄDEK-MOSZCZAK, A., DWORNICKA, R., BRONČEK, J., PIETRASZEK, J. The impact of laser processing parameters on the properties of electro-spark deposited coatings. Arch. Metall. Mater. 2018, vol. 63, pp. 809-816.

[47] WOJNAR, L., GADEK-MOSZCZAK, A., PIETRASZEK, J. On the role of histomorphometric (stereological) microstructure parameters inthe prediction of vertebrae compression strength. Image Analysis and Stereology. 2019, vol. 38, pp. 63-73.

[48] PIETRASZEK, J., GOROSHKO, A. The heuristic approach to the selection of experimental design, model and valid pre-processing transformation of DoE outcome. Adv. Mater. Res.-Switz. 2014, vol. 874, pp. 145-149.

[49] SKRZYPCZAK-PIETRASZEK, E., REISS, K., ZMUDZKI, P., PIETRASZEK, J. Enhanced accumulation of harpagide and 8-O-acetyl-harpagide in Melittis melissophyllum L. agitated shoot cultures analyzed by UPLCMS/MS. PLOS One. 2018, vol. 13, no. e0202556.

[50] JASIEWICZ, B., PIETRASZEK, J., DUDA, S., PIETRZAK, S., PRUSZCZYŃSKI, B., PAROL, T., POTACZEK, T., GADEK-MOSZCZAK, A. Inter-observer and intra-observer reliability in the radiographic measurements of paediatric forefoot alignment. Foot and Ankle Surgery. 2021, vol. 27, pp. 371-376.

[51] PIETRASZEK, J., GA̧DEK-MOSZCZAK, A., RADEK, N. The estimation of accuracy for the neural network approximation in the case of sintered metal properties. Studies in Computational Intelligence. 2014, vol. 513, pp. $125-134$ 